nature

medicine

\section{Plus ça change,}

$\mathrm{P}$ lus c'est la même chose. The more things change, the more they stay the same. In the wake of the 2 November presidential election in the US, we hope that the inverse of the saying will prove true. If the scientific enterprise in the US is to maintain its integrity and pre-eminence, change is imperative.

A quick glance at the last four years suggests that scientific input into key policy decisions has become devalued. Whereas predecessors relied on the office of the Assistant to the President for Science and Technology, President Bush removed the title, and possibly the implicit influence, from his science advisor, John Marburger, appointed a full 10 months into the administration's first term. Marburger himself said at the outset of his appointment that he did not expect much of an audience with Bush. Daily meetings with senior staff have likely changed this view, but Marburger's initial impression underscores the outside perception that science holds a backseat status in Washington.

Objective scientific advice is crucial to formulating sound policy. The US Food and Drug Administration (FDA) has been without a commissioner for all but 16 months of the last four years and is presently embroiled in controversy over antidepressants, Vioxx and the flu vaccine shortage. The recent announcement of plans by the FDA to sponsor a study by the Institute of Medicine on drug safety issues is promising. Filling the commissioner's post would help reassure the public that the agency has a voice, direction and accountability.

In 2003, the National Cancer Institute (NCI) published on its website (and later edited) that breast cancer might be linked to abortion or miscarriage-despite ample evidence debunking this claim, including that provided by a panel of analysts convened by the NCI. Several states continue to distribute government-issued pamphlets reiterating this link to women awaiting abortions. And of the President's $\$ 15$ billion Emergency Plan for AIDS Relief, a substantial amount is destined for programs to promote abstinence. Such decisions reinforce the urgent need for separating ideology and science policy.

Recently, direct congressional involvement in decisions on peer-reviewed research grants has challenged the authority and independence of regulatory agencies and the legitimacy of their decisions. In September, the US Congress voted to ban the funding in 2005 of two psychology studies (although the funds in these cases have been disbursed). In 2003, a failed attempt by Congress to restrict funding of studies of sexual research left researchers scrambling for euphemisms to avoid having their grants 'flagged' by the administration. George Bush recently affirmed "Competitive peer review is the cornerstone of the scientific establishment" (Science 306, 46-52; 2004). Given this assertion, why is the process being undermined?

This year, responding to Congressional concerns about conflicts of interest, the US National Institutes of Health (NIH) instituted a one-year moratorium for all NIH staff on consulting for industry and seeks a permanent ban for all senior $\mathrm{NIH}$ employees. The review by the NIH of consulting and conflictof-interest policies is a positive step, and restrictions may be warranted, but caution must be exercised to avoid loss of researchers to extramural positions and the productivity derived from public-private interactions.

The intersection of science and politics may be most keenly felt in the discourse on stem cells. In February of this year, two prominent researchers, Elizabeth Blackburn and Robert May, were dismissed from the President's Council on Bioethics, ostensibly for their support of expanded research on embryonic stem cells - a view at odds with that of the administration. The role of the council is to advise the administration on stem cell research and its ramifications, but it is also charged with considering the "consequences of limiting scientific research" (Executive Order 13237, Sec. 2 (b)). To best assess the therapeutic potential of research on embryonic stem cells and provide objective, unbiased advice, the council must maintain a diversity of opinions and expertise, rather than silence dissenting voices. And although the politically driven appointments to non-binding advisory bodies may be dismissed in view of the lack of power they wield, they are nevertheless effective tools for public persuasion and their impact should not be underestimated. With the approval of Proposition 71 to amend the California constitution to create an institute for stem cell research and the United Nations vote on proposals to ban all forms of cloning, the stem cell debate is far from over.

In February of 2004, the Union of Concerned Scientists issued a report decrying the performance of the Bush administration in handling scientific information and compromising the independence of scientific advisory panels and the integrity of their recommendations by loading them with members sympathetic to their beliefs. The conclusions prompted a separate investigation by the National Academy of Sciences into the selection process of federal science appointees. The next four years provide the opportunity for the government to improve their record. But if change is to occur, the scientific community has an active role to play. Scientists are accustomed to argument and their words are powerful even outside their usual province. 